\title{
ENPP3 wt Allele
}

National Cancer Institute

\section{Source}

National Cancer Institute. ENPP3 wt Allele. NCI Thesaurus. Code C147047.

Human ENPP3 wild-type allele is located in the vicinity of $6 q 23.2$ and is approximately 119

$\mathrm{kb}$ in length. This allele, which encodes ectonucleotide

pyrophosphatase/phosphodiesterase family member 3 protein, is involved in the

hydrolysis of phosphodiester and phosphosulfate bonds. 